\title{
Analysis of Physical Ability, Technique and Mental Condition of Indonesian National Karateka
}

\author{
Fransiskus Nurseto Subekti ${ }^{1}$, Soegiyanto ${ }^{2}$, Sulaiman $^{2}$, Hari Setijono $^{3}$ \\ ${ }^{1}$ Sports Education Program, Universitas Negeri Semarang, Indonesia \\ ${ }^{2}$ Faculty of Sports Science, Universitas Negeri Semarang, Indonesia \\ 3Faculty of Sports Science, Universitas Negeri Surabaya, Indonesia \\ Corresponding author : setobabe@yahoo.co.id
}

\begin{abstract}
Training practices with complex skills in body movements cannot rely only on the skills by themselves but also need relevant and perfect preparation, since good movements of the body are always supported by physical and mental conditions of the performers. This research was intended to analyze the physical and mental conditions as well as the techniques needed for best performances in karate events. The research sample consisted of 11 national karate athletes of Indonesia.This research measures and tests the following variables: 1) Physical consists of reaction speed, leg power, abdomen and shoulder. Agility and fleksibility 2) Self-efficacy. 3) Technique gyaku tsuki chudan. Based on Normative Physical Tests, the averages of both reaction speeds and powers were very good, agility was good and fleksibility was perfect. The techniques of "gyaku tsuki chudan" gained the average score resulted was very good. Tests on self- efficacy showed an average score of high category. It is hoped that the findings of this research might be useful for developing more focused and well oriented training programs, for analyzing the technical skills of the trainer and might also be used as barometers for the achievements of Indonesian karate athletes.
\end{abstract}

Keywords: Reaction Speeds, Agility, fleksibility, Self-efficacy and Gyaku Tsuki Chudan

\section{Introduction}

Karate came into Indonesia in 1963. It was brought by Indonesian students after finishing their education in Japan. Quantitatively, this sport of karate spread tremendously until small villages, as evidenced by 34 provinces in Indonesia and 25 active karate schools (Congress of PB FORKI, 2016). As a branch of sport, karate developed tremendously, beginning from sub branch to municipal and up to national levels. Such a big quantity then produced numerous national and international championships under the formal agendas of PB FORKI. Data from an analysis on Initial Physical Tests for the sport of karate (May, 10, 2016 by PRIMA or Gold Indonesian Program) were not in accord with the predetermined targets for Gold Production by Indonesian karate athletes from the ASEAN Games. Based on the Normative Physical Tests, the average score produced was only in medium category.

Documented issued by PB FORKI's Committee for National Karate Championship 2017 showed that $81,94 \%$ of the karate athletes used the techniques of gyaku tsuki chudan. In karate championship for the Indonesian ARMY Chief's Trophy 2017 in Jakarta 81,33\% and POPNAS XIV, 2017 in Semarang, 79,09\% of the karate athletes used the technique of gyaku tsuki chudan. In O2SN, 2017 in Medan, 87,34 \% in PPLP versus PPLD in Padang and in Mendagri Karate Championship, 2017, in Lampung, $80 \%$ of the athletes used the same technique.

The technique of gyaku tsuki chudan is very variative and efficient for collecting scores. This fact was acknowledged by the Indonesian athletes for karate. They felt more confident by using the technique of gyaku tsuki chudan as compared with some other techniques. They felt it even more when they had not got any point or when the status of the match is a draw. "that $70 \%$ of all techniquesm karate uses a lot of punches as a powerful weapon, by reason it's a karateka must have a really good punch to be able to earn points when in battle or kumite" (Purba,2016)

The importance of such factors as psychological and mental conditions supporting the technical skills should be fully understood in order to get optimum achievements. Unfortunately, however, these have not been understood well by karate trainers. Sport achievements can be achieved through correct and good guidance and trainings (Bompa, 1999). Physical condition constitutes a very important element in nearly all branches of sport, particularly for supporting other aspects such as techniques, tricks and mental condition 
(Yunyun, 2010). An athlete with good physical condition would be prevented from potential physical injuries that otherwise usually occurred in someone doing physical heavy works (Harsono, 2017). The dominant physical condition of karate components is agility, balance, strength, speed and flexibility. In the training process to improve the performance of athletes, must be considered components of the physical condition of karate is dominant. .(Putranto, 2015)

Based on the above background, a research studying the physical conditions, techniques of striking and mental conditions of karate athletes is really needed. The findings of such a research might then be used as barometers for athletes' achievements. The sample of this research consisted of Indonesian karate athletes having had champion statuses in the World events (3 athletes) and in ASIA events (4 athletes) and 4 other athletes who were champions in South Eastern Championship for Karate. When this research was being conducted, these 11 national-level athletes of karate were focusing themselves in training sessions as a preparation for World Championship for Karate conducted from October 26 to 29in Santa Cruz de Tenerife, Spain. This research was intended to analyze (1) the physical and mental conditions needed for best performances of karate athletes and (2) the real world physical \& mental conditions and technical skills of the subjects.

The findings of this research might then be used as a reference for developing and implementing better training programs and as a barometer for the physical, mental condition and technical abilities of Indonesian karate athletes.

\section{Methods}

The population for this research consisted of 11 Indonesian national-level male karate athletes (ages 14 to 18) for the year of 2017. For collecting the needed data (reaction speeds, powers, agility, fleksibility, mental conditions and gyaku tsuki chudan), we conducted the necessary tests and measurements based on the established standard operational procedures (Nurhasan, 2010). This research was conducted in Jakarta on October, 18, 2017. The location of the research was the Training Center for the Indonesian karate athletes.

Reaction speeds of the arms and legs were measured using the design of Whole Body Reaction. The three components of power (leg muscles, abdomen muscles and shoulder muscles) were measured by means of vertical jumps, sit ups and push-ups, respectively for 10 seconds each. Agility of the subjects were measured using 6-cone agility tests. Fleksibility were measured using gliding tests.

Finally, each of the subjects executed gyaku tsuki chudan strikes, each also for 10 seconds. For self- efficacy, the subjects answered the questionnaires that had been prepared. The physical and technical tests were executed twice each, from which the higher scores produced were used as the standards for valuations.

\section{Data Analyses}

The data coming from the physical, technical and mental measurements were then analyzed statistically and descriptively in order to find the highest and the lowest scores and the means. The standard scores were obtained from normative tests on the subjects' physical and technical conditions (TB FORKI). The results are presented in Table 1

Table 1. Normative Physical \& Technical Tests on the Subjects

\begin{tabular}{|c|c|c|c|c|c|c|}
\hline $\mathrm{N}_{0}$ & Test Components & Thy Pou & Poer & Avrage & Good & Exclent \\
\hline 1 & $S_{i t} T_{p}$ & 86 & $6-9$ & $10-13$ & $14-17$ & 217 \\
\hline 2 & Pust V. & $<4$ & $8-5$ & $9-12$ & $13-15$ & $>16$ \\
\hline 3 & Gide Test & $<11 \mathrm{~m}$ & $12-15 m$ & $16-19 \mathrm{~m}$ & $20-23 \mathrm{~cm}$ & $224 \mathrm{~cm}$ \\
\hline 4 & Thral Jum & $<55 \mathrm{~m}$ & $56-59 \mathrm{~m}$ & $60-64 \mathrm{~m}$ & $65-69 \mathrm{~cm}$ & $270 \mathrm{~cm}$ \\
\hline 5 & 6 Cons & $>6.01$ & $553-6.00$ & $545-5.2$ & $544-537$ & $<5.36$ \\
\hline 6 & Legs' Reaction & $>0.21$ & $0280-10213$ & $0212-0.2055$ & $0.204-0.197$ & $<1) .196$ \\
\hline$?$ & Amb' Besctio & $>0.197$ & $0.196-10.199$ & $0.188-0.181$ & $0.180-0.173$ & $<1.172$ \\
\hline 8 & Ggahu Tshin & 85 & 26.29 & $29-31$ & $32-35$ & 236 \\
\hline
\end{tabular}

\section{Results and Discussions}

\section{a. The scores for arm and leg reaction speeds of the Subjects}

The collected data were processed statistically and descriptively aided by SPSS 22 Windows program. The results are as follow: Data scores for Arms' Reaction Speeds. minimum 0.157, maximum 0.198 and mean 0,180 . Based on the physical Normative tests, the mean for arms' reaction speeds is classified into a very good category.

Data scores for Legs' Reaction Speeds, minimum 0.174, maximum 0.207 and mean 0,192 . Based on the physical Normative tests, the mean for Legs' reaction speeds is classified into a was perfect. 


\section{b. The scores for powers (shoulder, abdomen and legs) of the Subjects}

Data scores for Shoulder powers, minimum 13, maximum 16 and mean 13.8182 . Based on the physical Normative tests, the mean for Shoulder powers is classified into a very good category.

Data skores for abdomen powers, minimum 13.00, maximum 16.00 and mean 14.7273.

Based on the physical Normative tests, the mean for Abdomen Powers is classified into a very good category.

Data skores for legs powers. minimum 60.00 , maximum 74.00 and mean 68.0000 . Based on the physical Normative tests, the mean for legs Powers is classified into a very good category.

\section{c. Scores for Agility}

Data skores for agility minimum 5.09, maximum 5.81 and mean 5.3955. Based on the physical Normative tests, the mean for agility is classified into a very good category.

\section{d. Scores for Fleksibility}

Data skores for fleksibility minimum 23.00, maximum 31.00 and mean 25.2727. Based on the physical Normative tests, the mean for fleksibility is classified into a category. was perfect

\section{e. The Scores for Gyaku Tsuki Chudan of the Subjects}

Data skores for gyaku tsuki chudan minimum 29.00, maximum 36.00 and mean 32.5455. Based on the physical Normative tests, the mean for the technique of gyaku tzuki chudan is classified into a very good category.

\section{f. The Scores for Self- Efficacy of the Subjects}

Data skores for self - efficacy minimum 196.00, maximum 224.00 and mean 209.9091.

Based on the average score, the mean for selfconfidences is classified into a high category.

Karate is a martial art that requires high fitness. This sport is dependent on maximum levels of strength, speed, power, and agilityIn general. (Davaran. Maryam. 2014). The above descriptions show that the reaction speeds of the subjects (Tables 2 and 3) were in a very good category. To reach a champion status, a karate athlete needs good physical and technical abilities as well as good strategies and mental condition. In order to win a fight, the athlete should be quicker than his/her opponent in executing striking and kicking attacks. The sampled subjects for this research were 11 Indonesian national-level karate athletes. They had ever got gold medals from national championships held by PB FORKI from September to October, 2017. After becoming the subjects in this research, 3 of the 11 karate athletes managed to become runner ups in the World Karate Championship held in October 26 to 29, 2017, in Santa Cruz de Tenerife, Spain. The reaction speeds of these athletes were in accord with Nakayama (2013) who stated: "On the other hand, skill performance speed is one of the most basic factors in karate."

The powers of the subjects in this research were in a very good category. Karate athletes having higher power would have higher reaction speeds in reacting to the opponent's attacks and in making counter attacks as well as in performing acyclic non-reactive moves while the arms are approaching the target. When the arms are about to arrive to the target, powers would play very important role for executing acyclic and sikoic reactive moves that would produce quick and well oriented strikes. To execute a good gyaku tsuki chudan strike, high speed and power of the arms are really needed (Saputra, 2017).

High scores for agility might be the results from varied fighting styles of the athletes, in accord with each of their personal characteristics. An aggressive athlete, for instance, would rely on speeds for producing scoring points from a real fight. On the contrary, a defensive athlete would tend to rely on counter attacks which need very high body agility. The ability to change body positions according to the needs during a fight (in which the athlete does not know first from what direction the opponent's attack is coming or if there is some other relevant situational factor) would affect the movements of the athlete. In this context, the athlete should adjust him/herself to the existing condition and to his/her opponent's attacking and defending mechanisms. Horicka (2013) pointed out: "agility has a speed component, but it is not the most important component of this trait. The basic definition of agility is too simplistic, because it is now thought to be much more complex involving not only speed, but also balance, coordination, and the ability to react to a change of the environment. 
A karate athlete with good fleksibility possesses more spacious rooms in his/her joints and also more elastic muscles that he/she is more able to coordinate other physical components for attacking the opponent. High body elasticity is very important for executing quick strikes. Sajoto (1995) pointed out that the ability to change body position quickly and correctly to the correct position without losing balance is possible only when the athlete possesses good fleksibility.

The gyaku tsuki chudan strikes executed by the subjects in this research were in a very good category. The very good category of gyaku tsuki chudan strikes executed by the subjects in this research might relate to other relevant components, namely very good physical conditions and high self-confidence. This is shown by the very good category of the technical abilities of the subjects in this research. On the other hand, very good powers and reaction speeds supported attacks and counter attacks. Good scores for the subjects' body agilities might be the results of different fighting styles suited to different personal characteristics of the subjects. Perfect valuations for the subjects' body elasticities were represented by systematical body movements in executing the striking techniques.

An athlete with a habit of hard and disciplined self-trainings, as if he/she were performing a real fight, would have high selfefficacy. When there is no good mental condition, good physical condition and perfect technical mastering are not absolute guarantee that the athlete would perform optimally. Approximately $80 \%$ of an athlete's performances are determined by psychological aspects (Dharma, 2002). The thinking pattern, emotional reactions and physical actions of an athlete during a fight are determined by the answer to the question of "how high is the athlete's self-confidence on his/her own ability to finish the work satisfactorily?".

Self- efficacy determines the choice for an activity. An activity demanding high selfconfidence is liked more than other activity demanding only low self-confidence (Bandura, 1997). Hard works deployed for an activity or a task imply that higher self-confidence produces harder works. In this context, high self-efficaci relates to perseveration. Self-efficacy affects one's emotional reaction and mindset. Selfefficacy can also be described as a function of self-belief in which an individual can accomplish a task. Thus it can be said that the high persistence associated with self-efficacy will inevitably lead to improvement. (Cherien.2013).

\section{Conclusions}

Based on the results and discussions some conclusions are:

1) Reaction speeds of the subjects' arms and legs were very good, 2) the powers of the subjects' shoulder, abdomen and legs were very good, 3) Agility of the subjects were good and 4) Fleksibility of the subjects were perfect. 5) The gyaku tsuki chudan strikes executed by the subjects were very good category. 6) selfefficacy of the subjects'were high. With very good physical conditions and mental condition, a karate athlete can execute strikes very quickly and the striking techniques would be more efficient and more effective. Power, speed, agility, fleksibility constitute bio motoric components and mental condition that should be mastered by karate athletes in order to perform well in real fights.

\section{References}

Bandura, A. 1997. Self-Efficacy The Exercise of Control. New York: W.H. Freeman and Company.

Bompa, T O. 1999. Theory and methodology of training. Dubuque: Kendall/Junt Publishing Company.

Davaran. Maryam. 2014. The Effect of a Combined (Plyometric-Sprint) Training Program on Strength, Speed, Power and Agility of Karate-ka Male Athletes. Research Journal of sport sciences. 2 ( 2 ). $38-44$.

Dharma, S . 2002. Psikologi Olahraga. Jakarta : Universitas Taruma Negara.

Harsono. 2017. Kepelatihan Olahraga, Teori dan Metodologi. Bandung: PT Remaja Rosdakarya.

Nakayama. 2013. Best Karate Fundamental. New York. Kodansha America

Nurhasan. 2010. Tes dan Pengukuran dalam Pendidikan Jasmani: Prinsip dan Penerapannya Jakarta: Depdiknas.

Purba, Hotliber. 2016. Upaya Meningkatkan Kecepatan Pukulan Gyaku Tsuki Chudan Melalui Bentuk Latihan Variation Of Body Drops Pada Siswa Putra Ekstrakurikuler Karate Sma Swasta Kristen Immanuel Medan Tahun 
2016. Jurnal Ilmu Kependidikan. 14 (3) : $1-161$.

Putranto, Ramandani. 2015. Hubungan Antara Ketebalan Lemak Tubuh Dengan Kondisi Fisik Atlet Karate Pelajar Putra. Unnes Journal of Sport Sciences. 4 (2) : $50-54$

Sajoto, M. 1995. Peningkatan dan Pembinaan Kondisi Fisik dalam Olahraga. Semarang: Dahara Prize.
Saputra. 2017. Pengaruh Latihan Karet dan Latihan Beban Terhadap Peningkatan Power Lengaan dan Kecepatan Pukulan Gyaku Tsuki Chudan. Jurnal Terapan Ilmu Keolahragaan Special Issue 01 Seminar Nasional Ilmu Keolahragaan 2017. 15 (2) : 25 - 32 .

Yunyun. 2010. Metodologi Kepelatihan. Bandung : Penerbit UPI. 